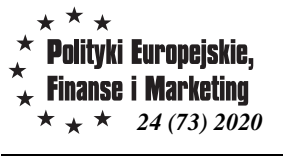

Marian Grzegorz Podstawka

Lukasz Grzegorz Podstawka

Warsaw University of Life Sciences - WULS
DOI $10.22630 /$ PEFIM.2020.24.73.36

\title{
TAXATION OF AGRICULTURAL ACTIVITY IN POLAND: THE CURRENT STATE AND FUTURE PROSPECTS
}

This study is a response to an ongoing debate on changes in the taxation of agricultural income. The current taxes applicable to farms in Poland do not concern income per se-they are property taxes which include: agricultural tax on land, forestry tax and property tax. Although these taxes do not refer to agricultural income, they are paid by it. It is important, therefore, to know how much this income is reduced by these taxes. Studies show that it is about $10 \%$. Therefore, when a new income tax structure is introduced, its rate should not exceed $10 \%$.

The calculation of farm income in Poland will encounter many problems, such as establishing a catalogue of costs, which will include depreciation. In order to include it when calculating income, the present value of a farm's fixed assets should first be established, which may encounter major substantive and organizational difficulties. More problems will surely follow, such as: dividing costs between household and agricultural holding, determining what a fixed asset is in the case of a farm, etc. It seems that calculating farm income is unavoidable. On the one hand, it is necessary for the potential introduction of income tax. On the other hand, having recognized the income situation of farms, one could resign from estimating losses caused by drought or other unfortunate events. Compensation could be granted due to income losses. This would be a clearer, more obvious and objective criterion. According to current practices, losses caused by unfortunate events (e.g. drought) do not always translate into losses in agricultural income, given that these losses are not always objectively estimated by the committees appointed by provincial governors. In the case of income losses, agricultural accounting data guarantee their objective appraisal.

The aim of the paper is to evaluate the current situation regarding the taxation of agricultural activity and to present proposals for potential changes in the taxation of agricultural activity. Two research hypotheses were put forward: 1. the current level of taxation of income and revenue from agricultural activity with agricultural tax and property tax is symbolic, 2. in order to maintain the current tax treatment, the rate of the new tax on farm income cannot be higher than 10\%. The article is based on descriptive, tabular and financial analysis methods. The sources of information were literature and FADN agricultural accounting data collected by the Institute of Agricultural and Food Economics - National Research Institute in Warsaw.

Keywords: farm, agricultural activity, agricultural tax, forestry tax, property tax, income tax, revenue tax, level of income taxation, level of revenue taxation

JEL Codes: Q14, H2

\section{Introduction}

The issue of taxation of agricultural activity in Poland has a long history. Over the years, various concepts have been developed. The purpose of this article is to join the discussion related to this issue and to offer suggestions to proposed changes in the 
agricultural tax structure. In order to propose a new approach, it is first necessary to assess the current situation regarding the taxation of agricultural activity. The first part of the study deals with that, and the second part concerns proposals for potential changes in the taxation of agricultural activity. The following research hypotheses have been put forward:

- Hypothesis 1. The current level of taxation of agricultural revenue and income through agricultural tax and property tax is nominal.

- Hypothesis 2. To preserve the current tax treatment, the rate of the new tax on farm income may not exceed $10 \%$.

In the study, the author used the descriptive, tabular and financial analysis methods. The study draws on literature and the FADN data gathered by the Institute of Agricultural and Food Economics - National Research Institute in Warsaw.

\section{Assessment of the rules for the taxation of agricultural activity}

Agricultural activity in Poland is subject to an agricultural tax, property tax, VAT and excise duty. If the farm includes a forest, it is also subject to a forestry tax. The agricultural tax was introduced by the Act of 15 November $1984^{1}$. Initially, until 1991, the agricultural tax had two forms. The first concerned agricultural land and the second concerned special sectors of agricultural production. Since 1991, special sectors of agricultural production have been taxed with PIT. Currently, agricultural tax on land is applicable. Its main role is to reduce the impact of differential rent on farming results. The redistributive role of this tax is negligible. Similar to land taxes applicable in the past, this type of tax has the same function. Its performance depends on the structural elements of agricultural tax (past land taxes). Agricultural tax is levied on natural persons, legal persons, organizational units without legal personality that are owners, independent and dependent holders and perpetual usufructuaries of farms. For the purposes of agricultural tax, a farm is understood as an area of agricultural land, land under ponds, woodland and shrubland whose total area exceeds 1 physical hectare or 1 conversion hectare.

The subject of taxation in agricultural land taxes is the estimated productivity of agricultural land, represented by valorization measures. These are conversion factors. Their span ranges from 1.95 to 0.05 . The differentiation of these factors depends on the quality of the agricultural land as well as its type and location in the tax district.

The agricultural tax rate is equivalent to 2.5 quintals of rye. The price of a quintal of rye is announced by the President of the Polish Central Statistical Office (GUS), who takes into account the changes in rye prices during the previous 11 quarters. Hence, agricultural tax is linear. Regardless of the farm area, the taxable person will pay the equivalent of 2.5 quintals of rye per 1 conversion hectare. Thus, this tax does not inhibit the development of farms, the increase in their intensity or productivity, nor does it diminish their profitability. Due to its structure, agricultural tax applies to one of the inputs (agricultural land) on which it is levied in specific conditions (municipalities) at the same level. Hence, if agricultural producers make good use of this potential, they will receive a bonus, because their revenue or income will not be heavily taxed. On the

\footnotetext{
${ }^{1}$ Dz. U. (Journal of Laws) of 1984 No. 52 item. 268
} 
other hand, inefficient producers who make worse use of the potential of agricultural land on their farm will suffer a kind of punishment, as their economic results will be taxed more heavily. There are a number of reasons to assess the agricultural tax positively. It is a reward for those who manage their farms well and a kind of punishment for those who do not make sufficient use of the production potential of their farms.

It is worth noting that the agricultural tax also applies to agricultural land that is not part of a farm. This situation takes place where a taxable person owns agricultural land, woodland or shrubland or land under ponds with an area of up to 1 physical hectare or 1 conversion hectare. In this case, the rate of agricultural tax is equivalent to 5.0 quintals of rye. In addition, for persons who own agricultural land in more than one municipality, in order not to be taxed with the higher rate of agricultural tax equivalent to 5.0 quintals of rye, such persons should inform the municipalities concerned about other land that they own. It may turn out that the total amount of land will be sufficient to constitute a farm for the purposes of the agricultural tax. There is only one condition: the taxable person in these municipalities must be the same.

Returning to the assessment of agricultural tax, determining its rate based on the price of rye is outdated. While 35 years ago it was the dominant grain in the crop structure and there were grounds to adopt its price as the tax rate, today, rye has a marginal share in the structure of the cropping pattern (approx. 5\% in 2015 ${ }^{2}$ ). Moreover, the structure of the agricultural tax does not allow for the implementation of mechanisms that foster the development of farms in the face of climate change. Such opportunities would be offered by an income tax that is applicable to farm income, as it would be possible to react through various types of support for those farms that have suffered a decrease in their income due to drought, flood, fire, etc.

The other tax levied on farms applies to residential buildings that are part of the farm ${ }^{3}$. Farmers pay this tax per $1 \mathrm{~m}^{2}$ of usable floor area of residential buildings. In 2020, the maximum property tax rate set by the Minister for Finance for residential buildings is PLN $0.81 \mathrm{per} \mathrm{m}^{2}$. If the farm includes lakes, the rate is nominal. In 2020, it amounts to approx. PLN 5 per 1 hectare of the lake area ${ }^{5}$. There are many reasons to use this situation as an example of failure to respect one of A. Smith's tax rules regarding "cheapness" in taxation ${ }^{6}$. According to this rule, tax collection costs should not exceed receipts. The case referred to above is contrary to this rule. It is worth adding that if a farmer conducts a business activity on land classified as agricultural land or woodland, this land is subject to property tax. In 2020, the maximum rate per $1 \mathrm{~m}^{2}$ of area is approx. PLN $29^{7}$, which is a rather high tax burden.

For example, a farmer who dedicates $5,000 \mathrm{~m}^{2}$ of land for a building depot or a car park will pay PLN 145,000 per annum. It should be noted that every year, the Minister

\footnotetext{
${ }^{2}$ B. Jaśkiewicz, A. Sułek: KIERUNKI ZMIAN PRODUKCJI ZBÓŻ W POLSCE Roczniki Naukowe. Stowarzyszenie Ekonomistów Rolnictwa i Agrobiznesu tom XIX. Zeszyt 1 of 2017, p.67

${ }^{3}$ Dz. U. (Journal of Laws) of 12.01 .191 on local taxes and fees

${ }^{4}$ Monitor Polski (Official Gazette of the Republic of Poland) of 17.07.2019 item 689

${ }^{5}$ Monitor Polski (Official Gazette of the Republic of Poland) of 17.07.2019 item 689

${ }^{6}$ A. Smith: The Wealth of Nations, Edited with Introduction and Note by Edwin Cannon, Random House Inc, New York, 1994

${ }^{7}$ Monitor Polski (Official Gazette of the Republic of Poland) of 17.07.2019 item 689
} 
for Finance sets the maximum rates of this tax. The total power to impose this tax is entrusted to municipalities, that may, by way of a decision from their decision-making body, set tax rates applicable to their area in the range from $50 \%$ to $100 \%$ of the maximum rates. Excessive liberalism in setting property tax rates as well as other taxes by municipal councils may result in receiving a smaller amount of the basic compensatory part of the general subsidy ${ }^{8}$. Property tax does not respect other tax rules, namely its amount is not proportionate to the taxable person's ability to pay. This is due to the fact that $1 \mathrm{~m}^{2}$ of usable floor area of a residential building or land, regardless of its value, is charged with the same tax rate. This is the main disadvantage of property tax. In the future, it will probably be replaced by an ad valorem tax, whose rates need to be very moderate. Otherwise, there could be an excessive tax burden.

The third charge imposed on farmers is a forestry tax ${ }^{9}$. Its new uniform structure has been in force since 1 January 2003. State forests and farm forests are subject to the same forestry tax. In this case the subject of taxation is the forest area in physical hectares. The maximum rate of this tax is announced annually by the President of the Polish Statistical Center Office (GUS) and is equivalent to $0.220 \mathrm{~m}^{3}$ of timber. In 2020 , the maximum forestry tax rate is PLN 42.73 per hectare ${ }^{10}$. It is worth adding that farmers are also subject to VAT and excise duties. These charges are not analyzed in this study, as no substantial changes are expected in their case. However, there are requests to simplify VAT by applying a zero rate on agricultural raw materials.

\section{Assessment of the level of taxation on farm revenue and income}

The FADN data has been used to assess the level of the taxation on farm revenue and income. It is a sample of over 12 thousand farms, representing all 700 thousand farms in Poland. Table 1 presents the agricultural tax on farm income by farming type.

\footnotetext{
${ }^{8}$ M. Podstawka: Problemy subwencjonowania gmin w kotekście ich władztwa podatkowego, [w:] Funkcjonowanie jednostek samorządu terytorialnego w wymiarze finansowo-prawnym, I. Kowalska, P. Możyłowski, T. Śmietanka (red.), Instytut Naukowo-Wydawniczy "Spatium”, Radom 2019, s.12-21 ${ }^{9}$ Act on forestry tax of 30 October 2002 Dz.U. (Journal of Laws) 2002 No. 200 item 1682

${ }^{10} \mathrm{https}: / /$ waw.infor.pl
} 


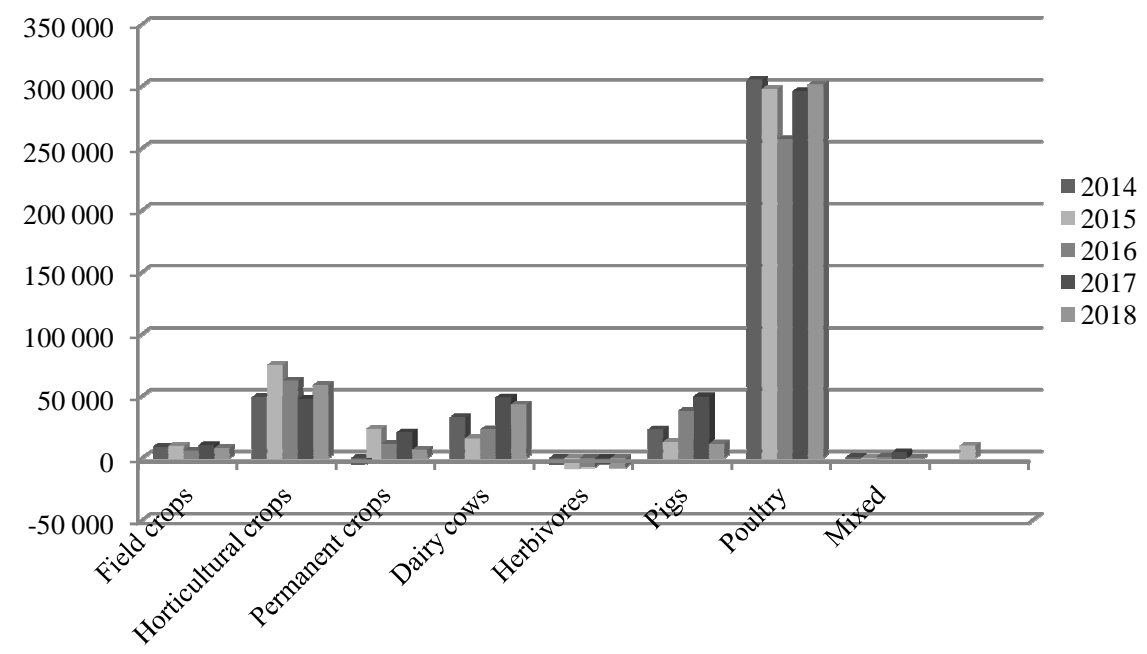

Chart 1. Farm income (without subsidies) in PLN in the years 2014-2018 by types of farming Source: authors' own study based on the FADN data for 2014-2018.

The information in Table 1 and on Chart 1 indicates a fairly differentiated level in the taxation of farm income with the agricultural tax. The worst situation is observed on farms rearing herbivores, suffering losses throughout the study period. Mixed farms are characterized by the greatest agricultural tax to income ratio, ranging from $19.44 \%$ in 2017 to $112.71 \%$ in 2014 .

Table 1. The level of agricultural tax on farms (without subsidies) by their production types in 2014-2018

\begin{tabular}{|c|c|c|c|c|c|}
\hline \multirow[b]{3}{*}{ Farm production types } & \multicolumn{5}{|c|}{ Year } \\
\hline & 2014 & 2015 & 2016 & 2017 & 2018 \\
\hline & \multicolumn{5}{|c|}{ Farm income (without subsidies) in PLN } \\
\hline Field crops & 9187 & 10061 & 6183 & 10565 & 8121 \\
\hline Horticultural crops & 49282 & 75165 & 62659 & 47658 & 59010 \\
\hline Permanent crops & -4733 & 23546 & 11602 & 20822 & 6846 \\
\hline Dairy cows & 33029 & 15957 & 23203 & 48997 & 43257 \\
\hline Herbivores & -4697 & -8471 & -7532 & -4986 & -7963 \\
\hline Pigs & 23129 & 13051 & 38096 & 49833 & 11760 \\
\hline Poultry & 305325 & 297767 & 257219 & 295850 & 301436 \\
\hline Mixed & 849 & -1095 & 1291 & 4701 & -908 \\
\hline \multirow[t]{2}{*}{ TOTAL } & 11835 & 10260 & 10992 & 16699 & 10910 \\
\hline & \multicolumn{5}{|c|}{ Agricultural tax per farm in PLN } \\
\hline Field crops & 1948 & 1922 & 1809 & 1694 & 1663 \\
\hline Horticultural crops & 441 & 480 & 482 & 455 & 461 \\
\hline Permanent crops & 985 & 999 & 863 & 831 & 807 \\
\hline Dairy cows & 1020 & 1033 & 1008 & 1020 & 1053 \\
\hline Herbivores & 839 & 872 & 876 & 805 & 779 \\
\hline Pigs & 1109 & 1176 & 1196 & 1250 & 1210 \\
\hline Poultry & 1298 & 1455 & 1471 & 1296 & 1142 \\
\hline Mixed & 957 & 960 & 933 & 914 & 958 \\
\hline \multirow[t]{2}{*}{ TOTAL } & 1186 & 1191 & 1144 & 1102 & 1110 \\
\hline & \multicolumn{5}{|c|}{ Share of agricultural tax in income $(\%)$} \\
\hline
\end{tabular}




\begin{tabular}{|l|r|r|r|r|r|}
\hline Field crops & 21.20 & 19.11 & 29.26 & 16.03 & 20.47 \\
Horticultural crops & 0.89 & 0.64 & 0.77 & 0.96 & 0.78 \\
Permanent crops & - & 4.24 & 7.44 & 3.99 & 11.79 \\
Dairy cows & 3.09 & 6.47 & 4.35 & 2.08 & 2.43 \\
Herbivores & - & - & - & - & - \\
Pigs & 4.80 & 9.01 & 3.14 & 2.51 & 6.12 \\
Poultry & 0.43 & 0.49 & 0.57 & 0.44 & 0.38 \\
Mixed & 112.71 & - & 72.25 & 19.44 & - \\
TOTAL & 10.02 & 11.61 & 10.41 & 6.60 & 10.18 \\
\hline
\end{tabular}

Source: the FADN data for 2014-2018.

A highly restrictive agricultural tax is also observed on farms specializing in field crops. In this case, agricultural tax to income ratios range from $16.03 \%$ in 2017 to $21.20 \%$ in 2014. As for other types of farms, the share of agricultural tax on their income is rather nominal. The best situation in this respect is observed on poultry farms. In this case, the average agricultural tax to income ratio over the analyzed years is approx. $0.40 \%$. Similar ratios are recorded on horticultural farms. In the case of these farms, the average agricultural tax to income ratio over the analyzed years was approx. $0.80 \%$.

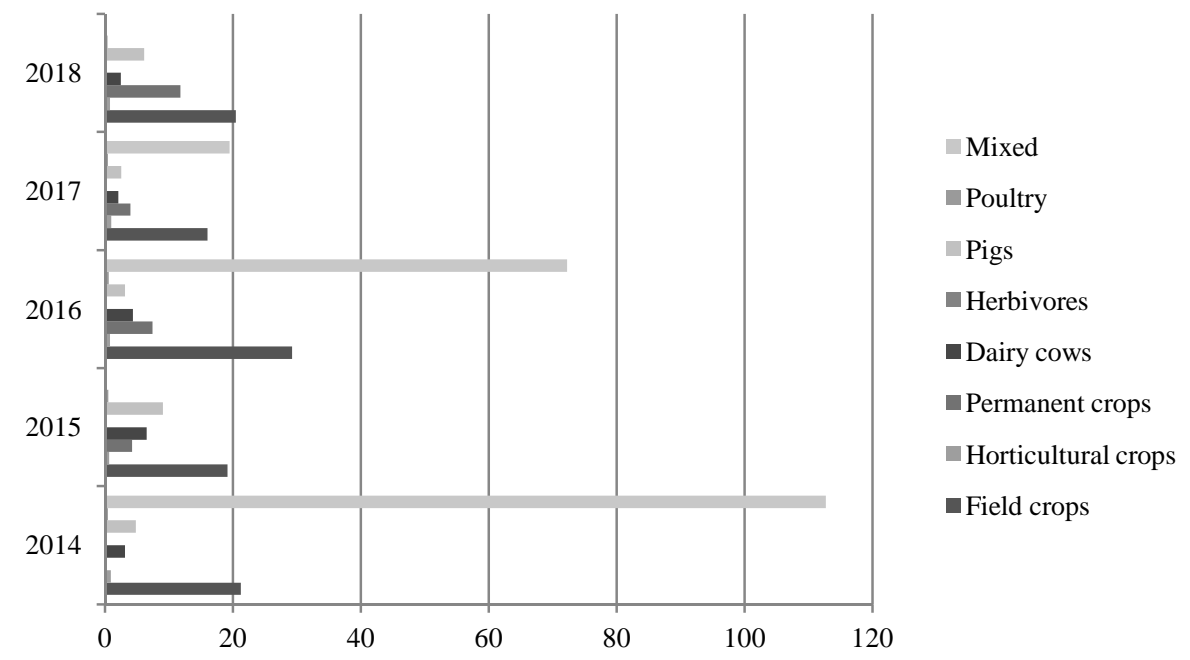

Chart 2. The share of agricultural tax in income (\%) on farms in the years 2014-2018 by types of production Source: authors' own study based on the FADN data for 2014-2018.

Table 2 shows the burden on income of various types of farms with all types of tax borne by agricultural producers (except for VAT and excise duties). 
Table 2. The total tax burden on farm income (without subsidies)

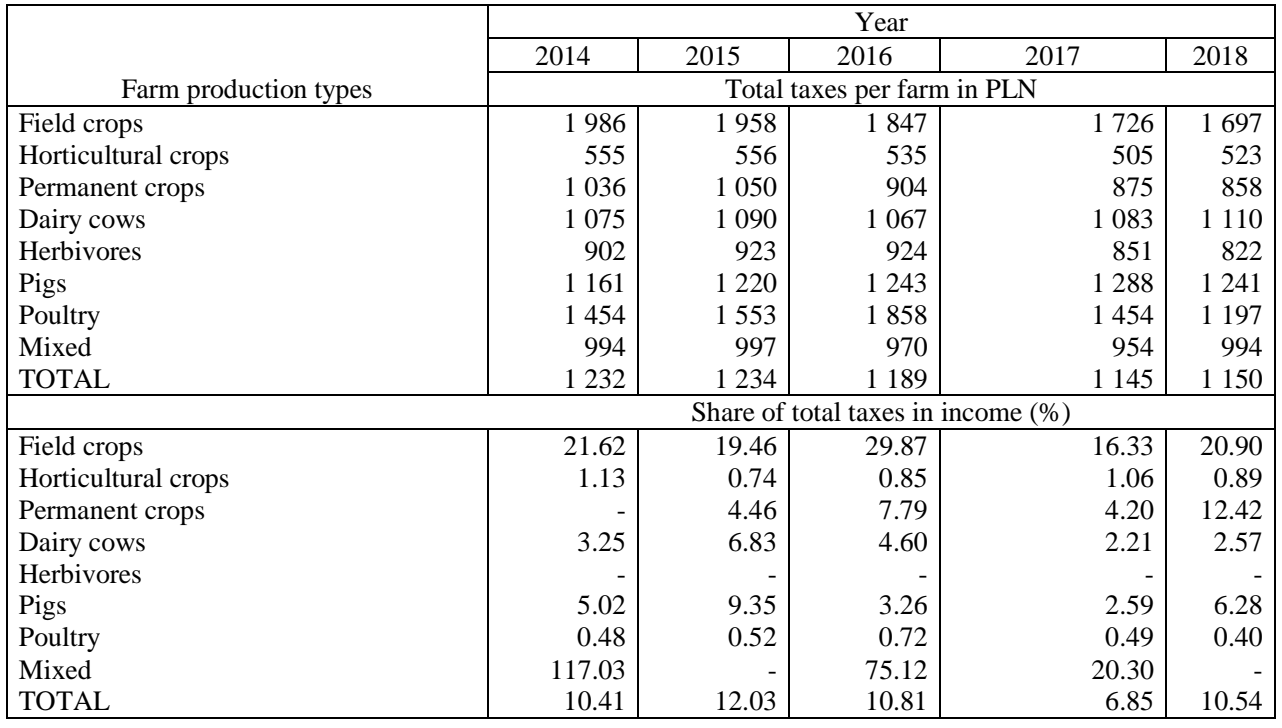

Source: the FADN data

The data in Table 2 clearly indicates that the level of total tax burden on the surveyed farms is slightly greater than the level of the agricultural tax burden on income. This means that other taxes (property tax, forestry tax) are a minor burden for farms.

As far as potential changes in farm taxation are concerned, it is worth assessing the level of tax burden on revenue generated by particular production groups. The relevant information is presented in Table 3.

The information provided in Table 3 indicates that agricultural tax has the greatest share in total sales of the surveyed farms. The share of all taxes in total sales is only slightly greater. As for farm production groups, the greatest burden with agricultural tax and total taxes is on total sales on farms dealing with field crops and herbivores.

Table 3. The level of burden of agricultural tax and total taxes on farms

\begin{tabular}{|c|c|c|c|c|c|}
\hline \multirow[b]{3}{*}{ Farm production types } & \multicolumn{5}{|c|}{ Year } \\
\hline & 2014 & 2015 & 2016 & 2017 & 2018 \\
\hline & \multicolumn{5}{|c|}{ Total sales per farm in PLN } \\
\hline Field crops & 88557 & 86733 & 84221 & 86834 & 89058 \\
\hline Horticultural crops & 207401 & 253667 & 239777 & 206968 & 199522 \\
\hline Permanent crops & 88233 & 101830 & 88426 & 92239 & 82813 \\
\hline Dairy cows & 129237 & 117373 & 119319 & 149860 & 157716 \\
\hline Herbivores & 40633 & 44330 & 42386 & 47337 & 47535 \\
\hline Pigs & 218270 & 193318 & 222405 & 265576 & 249360 \\
\hline Poultry & 2029926 & 2118712 & 1820112 & 1701628 & 1390761 \\
\hline Mixed & 54257 & 53903 & 54178 & 61366 & 62602 \\
\hline \multirow[t]{2}{*}{ TOTAL } & 100771 & 99672 & 98702 & 102360 & 98710 \\
\hline & \multicolumn{5}{|c|}{ Share of agricultural tax in total sales (\%) } \\
\hline Field crops & 2.20 & 2.22 & 2.15 & 1.95 & 1.87 \\
\hline Horticultural crops & 0.21 & 0.19 & 0.20 & 0.22 & 0.23 \\
\hline Permanent crops & 1.12 & 0.98 & 0.98 & 0.90 & 0.97 \\
\hline
\end{tabular}




\begin{tabular}{|c|c|c|c|c|c|}
\hline Dairy cows & 0.79 & 0.88 & 0.85 & 0.68 & 0.67 \\
\hline Herbivores & 2.06 & 1.97 & 2.07 & 1.70 & 1.64 \\
\hline Pigs & 0.51 & 0.61 & 0.54 & 0.47 & 0.49 \\
\hline Poultry & 0.06 & 0.07 & 0.08 & 0.08 & 0.08 \\
\hline Mixed & 1.76 & 1.78 & 1.72 & 1.49 & 1.53 \\
\hline TOTAL & 1.18 & 1.20 & 1.16 & 1.08 & 1.12 \\
\hline & \multicolumn{5}{|c|}{ Share of total taxes in total sales $(\%)$} \\
\hline Field crops & 2.24 & 2.26 & 2.19 & 1.99 & 1.91 \\
\hline Horticultural crops & 0.27 & 0.22 & 0.22 & 0.24 & 0.26 \\
\hline Permanent crops & 1.17 & 1.03 & 1.02 & 0.95 & 1.03 \\
\hline Dairy cows & 0.83 & 0.93 & 0.89 & 0.72 & 0.70 \\
\hline Herbivores & 2.22 & 2.08 & 2.18 & 1.80 & 1.73 \\
\hline Pigs & 0.53 & 0.63 & 0.56 & 0.49 & 0.50 \\
\hline Poultry & 0.07 & 0.07 & 0.10 & 0.09 & 0.09 \\
\hline Mixed & 1.83 & 1.85 & 1.79 & 1.56 & 1.59 \\
\hline TOTAL & 1.22 & 1.24 & 1.20 & 1.12 & 1.17 \\
\hline
\end{tabular}

Source: FADN.

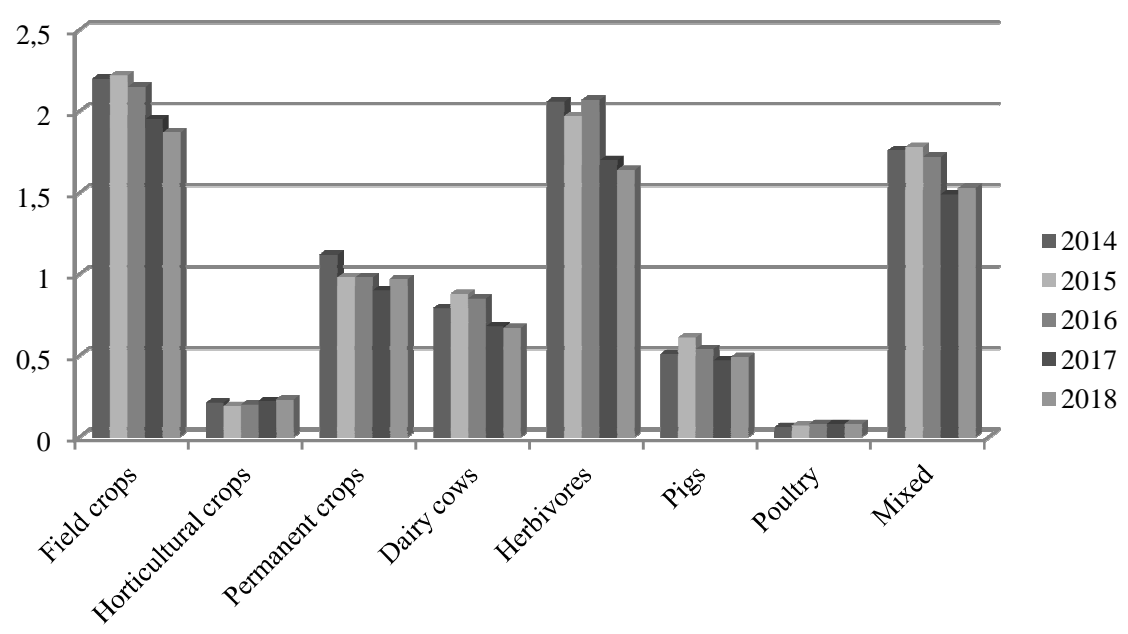

Chart 3. The share of agricultural tax in total sales (\%) on farms in the years 2014-2018 by production types Source: authors' own study based on the FADN data for 2014-2018.

The ratio of the fiscal burden to total sales on these farms is approx. $2 \%$. The most favorable ratio of tax burden to total sales is recorded on farms dealing with poultry, horticultural crops, pigs and dairy cows. The taxes on total sales on poultry farms are nominal. In the analyzed years, the tax burden share ratios ranged from $0.06 \%$ to $0.10 \%$. 


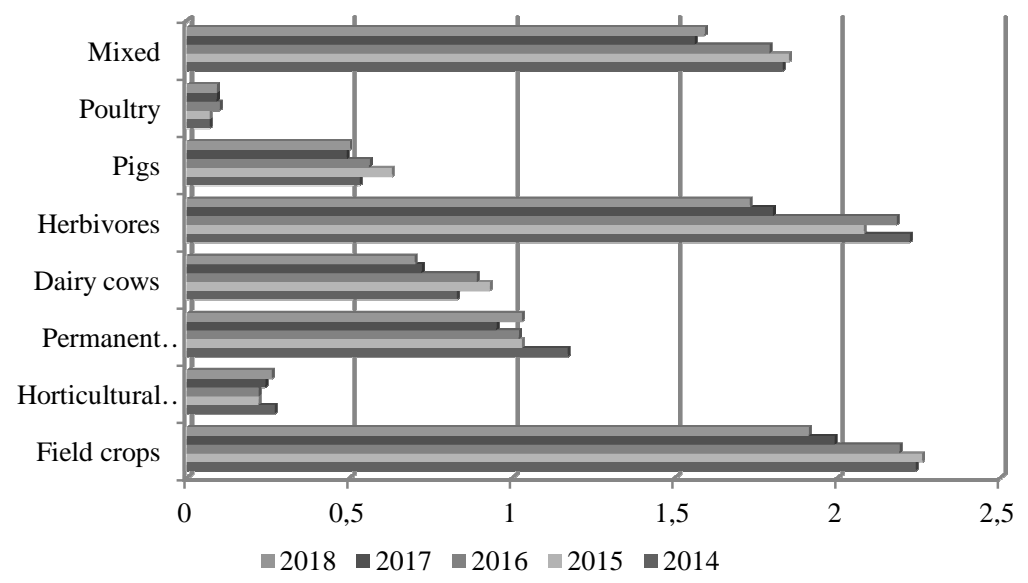

Chart 4. The share of total taxes in total sales (\%) on farms in the years 2014-2018 by production types Source: authors' own study based on the FADN data for 2014-2018.

\section{Prospects of taxation of agricultural activity on farms}

As previously mentioned, in 1991, some part of agricultural activity, namely income from special sectors of agricultural production, was taxed with PIT. Income from typical agricultural activity is not subject to income tax. If the rules for taxation of agricultural activity were to be changed, particular emphasis should be put, first of all, on the rules for and organization of calculating farm income and, secondly, the amounts of the tax rates. It seems that calculation of income would be more problematic. Not all farmers would be able to calculate it. This problem can be solved by accounting agencies. However, determination of depreciation as one of the main tax-deductible costs would be quite a challenge.

To calculate depreciation, farm assets should be measured beforehand, which brings about another problem. It would be possible for farm revenue to be taxed and then there is no problem with depreciation. However, taxation of revenue is of little use when trying to compensate for losses in agriculture caused by, e.g. drought. As far as the rate of presumptive income tax is concerned, it should be around $10 \%$ to preserve the current burden on farms from all taxes. For some farm production types this would increase the tax burden. These types include: poultry and pig farms, farms with dairy cows or farms dealing with horticultural crops. On the other hand, for some farm production types, a $10 \%$ income tax rate would reduce the current tax burden. These types of taxable entities would include farms dealing with field crops, herbivores or mixed farming. However, if revenue is to be taxed while maintaining the current burden level, the rate of such a tax should not be higher than $1 \%$. 


\section{Summary}

The study deals with the issue of taxation of agricultural activity in Poland. It consists of two parts. The first part evaluates the current state of taxation of agricultural activity in Poland. The second presents proposed changes in the taxation of this type of activity, taking into account the consequences of such changes. The study is based on literature and agricultural accounting data (FADN) collected by the Institute of Agricultural and Food Economics - National Research Institute in Warsaw. Two hypotheses were put forward. According to the first, the level of taxation of agricultural income in Poland is somewhat symbolic. The second assumes that while maintaining the current level of taxation of agricultural income, the tax rate cannot exceed $10 \%$. The study uses descriptive, tabular and financial analysis methods.

At present, the agricultural income of farms in Poland is subject to land, forestry and property taxes. The study does not take into account VAT, regarding it as a neutral burden from the point of view of agricultural income from farms.

The largest share of agricultural tax on income in the years 2014-2018 is held by mixed farms. This relation ranged from $19.44 \%$ in 2017 to $112.71 \%$ in 2014 . Subsequently, a relatively high share of agricultural tax on income was distinctive of farms engaged in field crops. In this case, the agricultural tax-to-income ratio was ca. $20 \%$. Relatively low values of the agricultural tax-to-income ratio were observed among the farms producing poultry and engaged in horticultural cultivation. In the case of these farms, the agricultural tax-to-income ratio did not exceed $1 \%$.

Taking into account all the tax burdens, we can notice a similar relation between them and their income among the surveyed farms. This leads to the conclusion that the agricultural tax is the main tax burden for farms. In relation to income, all tax burdens have the highest share among mixed farms. It ranges from $20.3 \%$ in 2017 to $117.03 \%$ in 2014. Next, a relatively high share of all taxes in relation to income occurs among farms engaged in field production. It ranged from $19.46 \%$ in 2015 to $21.62 \%$ in 2014 . The remaining farms were burdened with much lower total taxes. Of all farms, those dealing with poultry and horticultural production had to pay the lowest amounts of taxes relative to their income. In the case of poultry farms, the relation of the total tax burden to their income was about $0.5 \%$ in the analyzed years. A slightly greater share of the total tax burden in income was observed among farms engaged in horticultural production. In the analyzed years, it amounted to ca. $1 \%$. On average, among all farms, the share of the total tax burden in their income was $10 \%$. This leads to the conclusion that by replacing the existing taxes with income tax, its rate should exceed $10 \%$, which would guarantee maintaining the current level of farm income taxation.

The study also evaluates the degree to which farm revenue is burdened with total taxes. The information presented in Table 3 indicates that this relation is within $1 \%$. However, as before, mixed and field crop farms have the worst figures in this respect. In the case of mixed farms, the level of burdening their income with total taxes was about $2 \%$. Studies show that if tax is imposed on the revenue of farms, then in order to maintain the current state and taxation level the rate of such a tax could not be higher than $1 \%$.

\section{References}

Act on forestry tax of 30 October 2002 Dz.U. (Journal of Laws) 2002 No. 200 item 1682

Dz. U. (Journal of Laws) of 1984 No. 52 item. 268

Dz. U. (Journal of Laws) of 12.01.191 on local taxes and fees

https://waw.infor.pl

Jaśkiewicz B., Sułek A.: KIERUNKI ZMIAN PRODUKCJI ZBÓŻ W POLSCE Roczniki

Naukowe. Stowarzyszenie Ekonomistów Rolnictwa i Agrobiznesu tom XIX. Zeszyt 1 of 2017, p. 67

Monitor Polski (Official Gazette of the Republic of Poland) of 17.07.2019 item 689

Monitor Polski (Official Gazette of the Republic of Poland) of 17.07.2019 item 689 
Podstawka M.: Problemy subwencjonowania gmin w kotekście ich władztwa podatkowego, [w:] Funkcjonowanie jednostek samorządu terytorialnego w wymiarze finansowo-prawnym, Kowalska I., Możyłowski P., Śmietanka T. (red.), Instytut Naukowo-Wydawniczy “Spatium”, Radom 2019, s.12-21

Smith A.: The Wealth of Nations, Edited with Introduction and Note by Edwin Cannon, Random House Inc, New York, 1994

\section{Stan i perspektywy opodatkowania działalności rolniczej w Polsce}

\section{Streszczenie}

Opracowanie wychodzi naprzeciw toczącym się dyskusjom w sprawie zmian opodatkowania dochodów pochodzących z działalności rolniczej. Aktualnie istniejące podatki, odnoszące się do gospodarstw rolnych w Polsce, nie odnoszą się do dochodów. Mają one charakter podatków majątkowych, do których należy: podatek rolny od gruntów, podatek leśny i podatek od nieruchomości. Podatki te mimo, że nie nawiązują do dochodów z działalności rolniczej, są z nich pokrywane. Ważnym jest jaką część tych dochodów pomniejszają. Z badań wynika, że jest to ok. $10 \%$. Stąd ewentualnie we wprowadzanym nowym podatku od dochodów jego stawka nie powinna przekraczać $10 \%$.

Obliczanie dochodów gospodarstw rolnych w Polsce będzie napotykać na wiele problemów. Jednym z nich będzie ustalenie katalogu kosztów, do których zaliczać będzie się amortyzacja. Aby ją uwzględnić w obliczaniu dochodów, należy wcześniej ustalić wartość bieżącą środków trwałych, wchodzących w skład gospodarstw rolnych. Mogą temu procesowi towarzyszyć spore trudności merytoryczne i organizacyjne. To jeden z wielu problemów. Prawdopodobnie będą i inne. Zaliczyć do nich można: podział kosztów na gospodarstwo domowe i gospodarstwo rolne, ustalenie co jest środkiem trwałym w gospodarstwie rolnym itp. Wydaje się, że liczenie dochodów $\mathrm{w}$ gospodarstwach rolnych jest nie uniknione. $\mathrm{Z}$ jednej strony jest to niezbędne dla ewentualnego wprowadzeniu podatku dochodowego. $\mathrm{Z}$ drugiej strony mając rozpoznaną sytuację dochodową gospodarstw rolnych można by zrezygnować z szacowania strat spowodowanych przez suszę, czy innymi zdarzeniami losowymi. Tytułem otrzymania rekompensat byłyby straty dochodów. Jest to kryterium bardziej klarowne oczywiste i obiektywne. Dotychczasowa praktyka wskazuje, że nie zawsze straty spowodowane zdarzeniami losowymi (suszę) przekładają się na straty w dochodach rolniczych. Zważywszy, że straty te nie zawsze są obiektywnie szacowane przez powoływane przez wojewodów komisje. W przypadku strat w dochodach, dane rachunkowości rolnej są gwarantem ich obiektywnej oceny.

Celem opracowania jest dokonanie oceny aktualnej sytuacji dotyczącej opodatkowania działalności rolniczej oraz przedstawienie propozycji ewentualnych zmian w opodatkowaniu działalności rolniczej. Przyjęto dwie hipotezy badawcze: 1. Aktualny stopień opodatkowania dochodów, przychodów z działalności rolniczej podatkiem rolnym, podatkiem od nieruchomości jest symboliczny, 2. Dla zachowania dotychczasowego ujęcia podatkowego stawka nowego podatku od dochodów gospodarstw rolnych nie może przekraczać $10 \%$. W artykule wykorzystano metody analizy opisowej, tabelarycznej i analizy finansowej. Źródłem informacji była literatura oraz dane rachunkowości rolnej FADN gromadzone przez Instytut Ekonomiki Rolnictwa i Gospodarki Żywnościowej - Państwowy Instytut Badawczy w Warszawie.

Słowa kluczowe: gospodarstwo rolne, działalność rolnicza, podatek rolny, podatek leśny, podatek od nieruchomości, podatek dochodowy, podatek od przychodów, stopień opodatkowania dochodów, przychodów

JEL Codes: Q14, H2 


\section{Information about authors:}

\section{prof. dr hab. Marian Grzegorz Podstawka}

Szkoła Główna Gospodarstwa Wiejskiego w Warszawie

Instytut Ekonomii i Finansów

ul. Nowoursynowska 166,

02-787 Warszawa

e-mail: marian_podstawka@sggw.edu.pl

ORCID: 0000-0002-3834-0743

\section{mgr Lukasz Grzegorz Podstawka}

e-mail: glpodstawka@gmail.com; lukasz_podstawka@sggw.edu.pl ORCID: 0000-0002-7374-0218 